\title{
Predicting the potential for old-growth forests by spatial simulation of landscape ageing patterns ${ }^{1}$
}

\author{
by Ajith H. Perera², David J. B. Baldwin², Dennis G. Yemshanov ${ }^{2}$, Frank Schnekenburger², \\ Kevin Weaver ${ }^{2}$ and Dennis Boychuk ${ }^{3}$
}

\begin{abstract}
Planning for old-growth forests requires answers to two large-scale questions: How much old-growth forest should exist? And where can they be sustained in a landscape? Stand-level knowledge of old-growth physiognomy and dynamics are not sufficient to answer these questions. We assert that large-scale disturbance regimes may provide a strong foundation to understand the spatio-temporal ageing patterns in forest landscapes that determine the potential for old growth. Approaches to describe large-scale disturbance regimes range from scenarios reconstructed from historical evidence to simulation of landscapes using predictive models. In this paper, we describe a simulation modelling approach to determine landscape-ageing patterns, and thereby the landscape potential of old-growth forests. A spatially explicit stochastic simulation model of landscape fire-forest cover dynamics was applied to a 1.8 million-ha case study boreal forest landscape to quantify the spatio-temporal variation of landscape ageing. Twenty-five replicates of 200-year simulation runs of the fire disturbance regime, at a 1-ha resolution, generated a suite of variables of landscape ageing and their error estimates. These included temporal variation of older age cohorts over 200 years, survivorship distribution at the $200^{\text {th }}$ year, and spatial tendencies of ageing. This information, in combination with spatial tendency of species occurrence, constitutes the contextual framework to plan how much old-growth forest a given landscape can sustain, and where such forest could be located.
\end{abstract}

Key words: landscape management, old growth, spatial simulation modelling, landscape ecology, boreal forest, Ontario, fire regime simulation, natural forest disturbances, stochastic models, age-class distribution

Il faut se poser deux questions à grande échelle lorsqu'on planifie pour des forêts anciennes : quelle étendue faut-il prévoir pour elles? et où peuvent-elles subsister dans un paysage? Pour répondre à ces questions, la connaissance de la physionomie et de la dynamique des forêts anciennes au niveau du peuplement ne suffit pas. Nous faisons valoir que les régimes des perturbations de grande échelle pourraient représenter une clé importante pour la compréhension des patrons spatiotemporels de vieillissement qui déterminent le potentiel pour une forêt ancienne dans les paysages forestiers. Les approches de description de ces régimes vont de l'élaboration de scénarios en s'appuyant sur des données historiques jusqu'à la simulation de paysages à l'aide de modèles prédictifs. Dans cette communication, nous décrivons une approche de modélisation produisant des simulations du vieillissement d'un paysage pour en déterminer le patron de vieillissement et, donc, le potentiel de développement de forêts anciennes. Un modèle de simulation stochastique spatialement explicite de la dynamique du feu et du couvert forestier a été appliqué à un paysage d'étude de 1,8 million d'hectares dans la forêt boréale en vue de quantifier la variation spatiotemporelle du vieillissement. Vingt-cinq répétitions de cycles de simulation de 200 ans du régime des perturbations par le feu, à une résolution de 1 ha, ont fait ressortir une série de variables du vieillissement du paysage et fourni des estimations de l'erreur s'y rattachant. Ces variables comprennent la variation temporelle sur 200 ans des cohortes plus âgées, la distribution des survivants à la $200^{\text {e }}$ année et les tendances spatiales du vieillissement. Cette information, combinée à la tendance spatiale de la présence des espèces, constitue le cadre contextuel de la planification concernant l'abondance de la forêt ancienne que peut soutenir un paysage donné et l'emplacement possible de cette forêt.

Mots clés : aménagement du paysage, modèle de simulation spatiale, écologie du paysage, forêt boréale, simulation des feux de forêt, perturbation forestière naturelle, modèle stochastique, distribution des classes d'âge

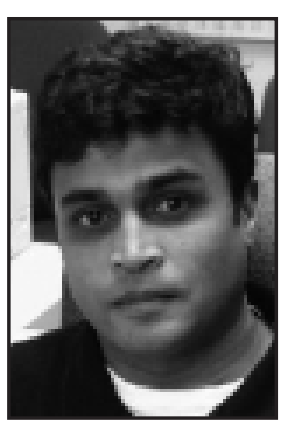

Ajith H. Perera

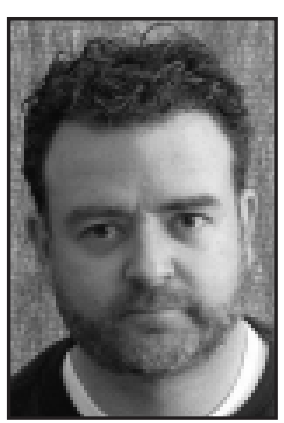

David J. B. Baldwin

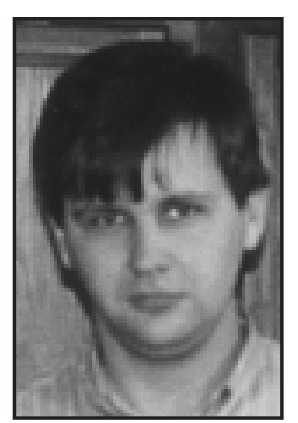

Dennis $G$. Yemshanov

\footnotetext{
${ }^{1}$ Paper presented at the "Old-growth Forests in Canada: A Science Perspective" Conference, October 14-19, 2001, Sault Ste. Marie, ON.

${ }^{2}$ Forest Landscape and Ecology Program, Ontario Forest Research Institute, 1235 Quean Street East, Sault Ste. Marie, Ontario P6A 2E5. E-mail: ajith.perera@mnr.gov.on.ca

${ }^{3}$ Ontario Ministry of Natural Resources, 70 Foster Drive, Suite 400, Sault Ste. Marie, ON P6A 6V5.
}

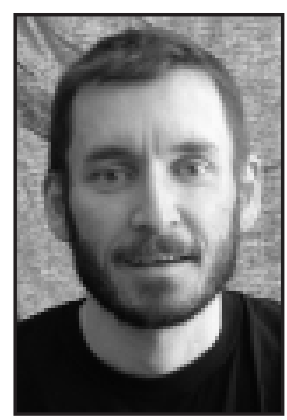

Frank Schnekenburger

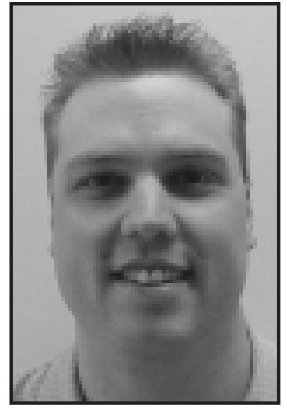

Kevin Weaver

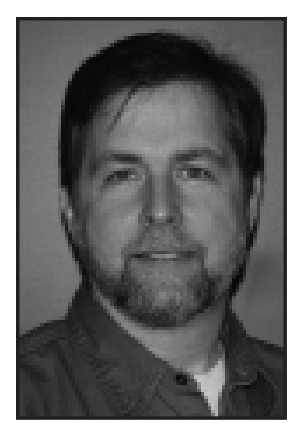

Dennis Boychuk

\section{Introduction}

When designing strategies to ensure sustainable existence of old-growth forests, policy makers and forest managers face numerous questions that encompass a range of spatial and temporal scales. Two important issues that emerge at regional and landscape scales are a) determining the desired extent 
of old-growth forests, and b) their spatial configuration, in particular, where these forests could occur in the landscape. Although the answers to these questions contain social, cultural, and economic dimensions, they must be founded first on rigorous ecological information to ensure sustainability of old growth.

Ecological knowledge about old-growth physiognomy (e.g., Hunter 1989, Spies and Franklin 1996), dynamics (e.g., Franklin and Spies 1988, Frelich et al. 1993), and patterns (e.g., Barnes 1989, Harris 1984, Mladenoff et al. 1993) is well advanced. This information helps practitioners to identify old-growth forest entities, their values, function, and changes. However, this knowledge alone is not adequate to determine the likelihood of old-growth survival and persistence at a landscape level because this is also a function of the large-scale disturbance regimes (Johnson et al. 1995, McKenzie et al. 2000, Wimberly and Spies 2001). This is especially true where local forest dynamics are nested within large-scale disturbance regimes (e.g., Lertzman et al. 1998). As a result, many attempts have been made recently to link large-scale disturbance regimes to old-growth forests. For example, Johnson et al. (1995) provided an excellent description of how large-scale disturbance regime information could be used to determine the extent of old-growth forest in a given landscape. Boychuk and Perera (1997) and Wimberly et al. (2000) also demonstrated how knowledge of long-term disturbance regimes could be used to understand variations in the old-growth component in a landscape over time. Therefore, it is logical that conservation strategies for old growth adopt a top-down approach and establish the necessary large-scale spatial and temporal context for using knowledge of stand-level structure and dynamics. A large-scale perspective enables practitioners to recognize that a) old growth can be defined from age cohort composition (e.g., Johnson et al. 1994, Kneeshaw and Burton 1998), and b) extent of old growth in a landscape can vary in time and space, and can be explained by temporal and spatial patterns of disturbance (e.g., Heinselman 1973, Johnson et al. 1990, Reich et al. 2001). Large-scale disturbance regimes are an a priori consideration for understanding temporal and spatial patterns of forest landscape ageing and, therefore, designing conservation strategies for old-growth forests in landscapes.

Approaches to understanding large-scale disturbance regimes can be grouped into two broad categories: historical reconstruction and simulation modelling. The first category includes various methods of extracting evidence of past disturbances (e.g., Suffling et al. 2003) and extrapolating that information to the future. The second category includes methods of theoretical prediction, based on empirical information (e.g., Johnson and van Wagner 1985), mechanistic processes (e.g., Finney 1999), or a hybrid of both (e.g., Keane et al. 1996). As a comprehensive review of these approaches is beyond the scope of this paper, we direct the reader to two excellent reviews for further details: Egan and Howell (2001) for natural history methods and Gardner et al. (1999) for predictive modelling methods. Although all simulation modelling approaches project disturbance regimes in time, they can be further categorized based on the variation (deterministic versus stochastic) and explicitness (spatial versus non-spatial) of the outcome. Stochastic disturbance models account for inherent variation in processes (e.g., fire ignition, spread, and extinguishment) and input (e.g., weather, fuel) and thereby predict outcomes of known probability. Spatially explicit models use geo-referenced data for input (e.g., land cover, climate, terrain) and produce geo-referenced output (e.g., age, species). They also explicitly scale model functions (e.g., fire spread in 100-m steps at one-hour intervals), and account for spatial processes (e.g., propagule dispersal).

The goal of this paper is to demonstrate how landscape potential (i.e., spatial extent and locations) for old-growth forest can be estimated by spatial simulation of large-scale forest disturbance dynamics. The premise of this approach is simple: at large spatial scales, patterns of forest ageing emerge as a function of the spatial and temporal stochasticity of dominant disturbance regimes, in addition to the influence of geo-climatic conditions. In this exercise, we use a large-scale, spatially explicit, and stochastic simulation model of fire disturbance-forest cover dynamics to simulate uncontrolled "natural" disturbances for sufficiently long periods to portray the spatio-temporal patterns of landscape ageing. By spatially explicit, we mean that all inputs and outputs of the model are geo-referenced, and geo-climatic conditions and neighbourhood effects at those points are incorporated into the modelled processes. The stochasticity stems from model functions being probabilistic and variability is captured by replicating model simulations. Finally, we emphasize that the content of this chapter is an illustration of the generic capability of the approach - not a detailed description of the forest disturbance ecology of the study area.

\section{Spatial Simulation Methods \\ Study area and assumptions}

We selected a 1.8 million-ha managed boreal forest area in Ontario, Canada, for this case study (Fig. 1). The study area is located in the Boreal Forest Region-Central Plateau (Rowe 1972) and NE3 of Hills' (1959) Ontario ecoregion classification. Spatial information on geoclimate (Ontario Ministry of Natural Resources 2000), soils (Ontario Ministry of Natural Resources 1977, Agriculture and Agri-Food Canada 1996), terrain (Centre for Topographic Information 2000), recent fire history (Perera et al. 1998), and forest inventory (Ontario Ministry of Natural Resources 1996) has been documented. Although this area is prone to periodic fire, the major disturbance in the last several decades has been forest harvesting, resulting in a legacy of forest age-class structure dominated by 50 - to 100 year-old stands. As such, we estimate the "natural potential" of landscape ageing based on non-pristine initial forest cover conditions. The forest cover composition of the study area is presently dominated by black spruce (Picea mariana), with lesser area of poplar (Populus spp.), white birch (Betula papyrifera), and jack pine (Pinus banksiana) (Fig. 1). We had to make several assumptions due to limitations in input data and other explicit knowledge. First, because the present forest inventories do not distinguish between the canopy age and site age, we assumed these to be equal in the input data. Second, because spatially reliable climate change models do not exist for the study area, we assumed that the climate conditions are stable during the simulation period. In addition, as spatially detailed fire weather data is available only after the1960s, we could not account for extremes in fire weather scenarios beyond those occurred during the last 40 years. Finally, to simplify this demonstration, we did not include possible interactions of fire regime with other large-scale processes such as insect pest epidemics. We discuss the implications of these assumptions in light of the simulated scenarios later. 


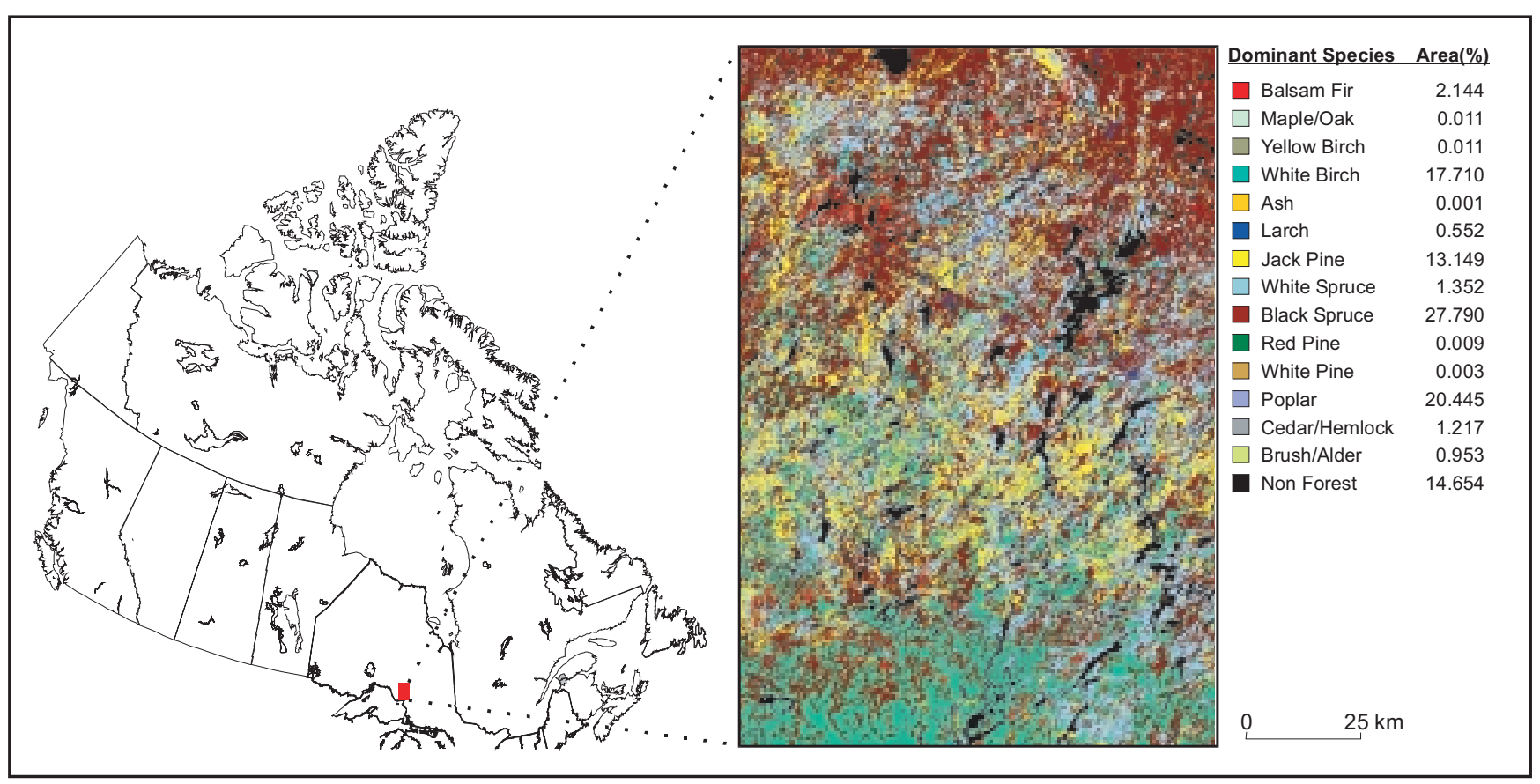

Fig. 1. Forest cover composition of the study area $(1.79 \mathrm{~m}$ ha) based on forest resource inventory data (Ontario Ministry of Natural Resources 1996).

\section{Simulation model}

We used the "Boreal Forest Landscape Dynamics Simulator" (BFOLDS) for this demonstration. BFOLDS (Perera et al. in press) is an integrated disturbance regime model, composed of a crown fire regime simulation module (FSM) and a vegetation transition module (VTM). It is designed to simulate fire-induced forest landscape dynamics over large areas $(>10$ $\mathrm{M}$ ha) for medium time frames (up to 300 years), at one-year time steps and at 1-ha cell-based spatial resolution. Input raster GIS data layers include canopy tree composition, canopy tree age, slope, aspect, soil moisture and nutrient status, fuel type, time since last disturbance, and a suite of climate variables.

The FSM is predicated on current knowledge of fire processes (e.g., fuel, terrain, and weather-aided fire ignition, spread, and extinguishment) and empirical input data (e.g., forest cover, canopy age, terrain). It does not assume predetermined characteristics of fire regime (e.g., maximum fire size, size-class distribution of fire). Instead, the predicted fire regime characteristics emerge as a result of fire behaviour (ignition, spread, and extinguishment) as a probabilistic function of forest cover, terrain, and weather. The FSM contains three sub-modules that are process based: fire ignition, fire spread, and fire extinguishment.

The fire ignition sub-module uses historical records (1963-1999) of annual distribution of daily lightning-caused fire ignitions in a given geographic area to seed potential fires. For each simulation year, a calendar year is randomly selected from these databases to provide daily estimates of historical forest fire weather indices and lightning-caused fire counts. The following indices of the Canadian Forest Fire Weather Index (FWI) System are used in the model: duff moisture code (DMC) - a rating of the moisture content of loosely compacted, decomposing organic layers of moderate depth; fine fuel moisture code (FFMC) - a rating of the moisture content of litter and fine cured fuels; and build-up index (BUI) — a rating of the total fuel available to a spreading fire (van Wagner 1987). For a given day of the simulation, the historical database is queried for the number of lightning-caused fires, $\mathbf{m}$, that occurred on that day. A random value, $\mathbf{n}$, is generated from a Poisson distribution with mean and variance of $\mathbf{m}$ (Cunningham and Martell 1973). The $\mathbf{n}$ potential ignitions are then placed randomly across the landscape in 1-ha cells; whether a fire "starts" or not depends on the forest cover and age-based fuel type, and the DMC where ignition occurs. A fire will not ignite if DMC is $\leq 20$, which represents the equilibrium moisture content in fuel (van Wagner 1987). Once ignited, a fire can spread to the neighbouring cells as simulated by the fire spread sub-module.

The fire spread sub-module uses a discrete-event simulation approach to managing major fire process events (e.g., Vasconcelos and Zeigler 1993). When a cell ignites, it is given an opportunity to spread to each burnable neighbouring cell, within a surrounding $5 \times 5$ window. Based on the fire weather database, DMC, FFMC, and BUI are estimated for the location and time of ignition. Species and age are used to derive fuel type, based on the 17 fuel type classes of the Canadian Forest Fire Behaviour Prediction (FBP) System (Forest Fire Danger Group 1992). Using the fire weather indices, fuel type, slope, aspect, wind speed, and wind direction as inputs into the FBP system, the model estimates the rate of spread (ROS) to each of the 24 neighbours. For a given cell, $\mathbf{c}$, the ROS is used to calculate the future time, $\mathbf{t}$, at which that cell may ignite; this information is stored as a discrete event in the model's event schedule. When time $\mathbf{t}$ arrives during the simulation, cell $\mathbf{c}$ may ignite, depending on weather conditions at that time. If the cell ignites, then the potential of the fire to spread to each of the cell's 24 neighbours is evaluated, as above. Fire spread may stop due to non-suitable fuel type in neighbouring cells and/or non-conducive weather. The fire extinguishment sub-module in the model is driv- 
en primarily by weather: if the combination of weather elements causes the DMC to rise above 20 (equilibrium saturation fuel moisture in a given cell, after van Wagner 1987), smouldering will cease.

The VTM comprises two steps: simulating forest cover transition and early recruitment of tree species. Forest cover transitions are simulated using a time-dependent transition discrete state (semi-Markovian) model using tree species dominance in a canopy as the discrete state descriptor of forest cover (Yemshanov and Perera 2002). The probability of forest cover persistence (lag between transitions) is simulated as a time-dependent process governed by two parameters for given climate and site conditions: the delay interval before it is eligible for replacement $\left(t_{\mathrm{d}}\right)$ and the maximum period of persistence before it is replaced $\left(t_{\mathrm{p}}\right)$. These values were collected for each tree species from the published knowledge on succession in the North American boreal biome (Yemshanov and Perera 2001). Temporal behaviour of the probability of $t_{\mathrm{p}}$ was modelled using Gamma probability density function. Published literature (e.g., Sirois and Payette 1989, Bergeron 2000) was used to derive proportions of other forest cover types replacing an extant forest cover type after $t_{\mathrm{d}}$. Following Logofet and Lesnaya (2000), these non-self-replacing transitions were constrained by all probabilities adding to 1 during a transition step. Transition probabilities for all species were stratified by ecological site condition variables, such as climatic zone, soil moisture, and nutrient status. For details on the forest cover transition sub-module see Yemshanov and Perera (2002).

The VTM step of early recruitment of tree species encompasses three sub-processes: seed production, seed arrival, and establishment. Seed production is modelled as function of tree species age, annual seed rain, year-to-year seed crop fluctuations, and other autecological characteristics. Simulations of seed rain years use the published historical data on seed production for each tree species (e.g., Zasada et al. 1992, Greene et al. 1999). The seed arrival process estimates the spatial distribution of the amount of viable seeds as a probabilistic function of annual seed production, distance from the nearest seed sources, and wind directions during the time of seed release. Using maximum and effective seed dispersal distances from the literature (e.g., Zasada et al. 1992), the model calculates seed dispersal vectors for each given location based on a given location and azimuth direction. It uses Gaussian dispersal kernel (Clark et al. 1999) to estimate seed arrival as a function of seed production and distance from the nearest seed source. The annual availability of viable propagules is simulated using the published knowledge on seed viability, longevity of soil seed bank, and seedbed suitability. The probability of species being established successfully during the three-year post-disturbance period is predicted as a function of seedbed suitability and the amount of viable propagules. Following Rupp (1998), seedbed suitability was represented as the species-specific probability of successful survival of germinants.

BFOLDS also contains a sub-module within the Vegetation Transition Simulator that accounts for spatial dependence of input data by applying spatial bias to the assignment of forest cover transition probabilities to reduce the artificial spatial randomness introduced by aspatial Markov models (Weaver 2002). Regions defined by the local spatial dependence of environmental site conditions are used to bias probability assignment in space so that similar forest cover types are more likely to occur close together. Spatial bias is only applied where site conditions exhibit positive spatial dependence and the degree of spatial dependence (e.g., low, intermediate, and high) is used to determine how much bias is applied.

If a 1-ha pixel is burned, the model assumes complete canopy destruction and replaces that cell with appropriate tree species based on the early recruitment sub-module. If a pixel is not burnt, its species may be replaced based on age and sitebased species transition probabilities of the vegetation transition sub-module. In either case, the time since burn and time since species transition are tracked annually. Fig. 2 provides a conceptual overview of BFOLDS.

\section{Simulation runs}

A 10-km buffer was added to the study area before the simulation runs to account for boundary effects of fires that originate outside. Model input comprised the spatial data layers of forest cover (Gillis and Leckie 1993, Ontario Ministry of Natural Resources 1996), soils (Ontario Ministry of Natural Resources 1977, Agriculture and Agri-Food Canada 1996), climate (Ontario Ministry of Natural Resources 2000), and terrain (Centre for Topographic Information 2000) at 1-ha resolution. We did not initialize the model runs in order to demonstrate the effect of an uncontrolled disturbance regime on the present patterns of landscape age. The simulation period was set for 200 years, with annual output of disturbance regime information. The decision for selecting 200 years as the simulation period was subjective, but we reasoned that the assumption of stable climate (as explained earlier) would be weaker with even longer simulation periods. Moreover, the experimental knowledge of successional trajectories in the published literature (on which the VTM is based) is sparse beyond 200 years. We replicated the disturbance dynamics simulations 25 times to capture the range of effects of the stochastic elements in BFOLDS. During the simulation runs, each of the 1.8 million pixels was monitored annually for burning and species transitions. This information was used to construct aspatial and spatial statistics of the fire disturbance regime and the post-disturbance landscape structure for the study area (Table 1). Because the time-since-last disturbance and the time-since-last forest cover transition was tracked separately for each 1-ha pixel during the simulation runs, a distinction could be made between the age of the dominant tree species (canopy age) and the time since last disturbance (site age) in the output.

\section{Simulation Results}

BFOLDS simulation runs generated a wide spectrum of variables on fire regime and landscape structure (Table 1). These include variables monitored annually during the simulation period and summary statistics that describe the overall disturbance dynamics for the entire simulation period. Most of these variables are spatially explicit, meaning that the values generated are geo-referenced at a 1-ha resolution for the landscape. Spatially explicit output enables landscape planners to estimate the spatial variability of the fire regime and landscape ageing patterns, and to assess the potential for old growth in a spatially precise manner. Furthermore, the multiple stochasticities in the modelled processes in BFOLDS are captured by replicates of the simulation runs, which can be expressed as a third dimension of variability, in addition to spatial and temporal source of variation of landscape ageing estimates. 


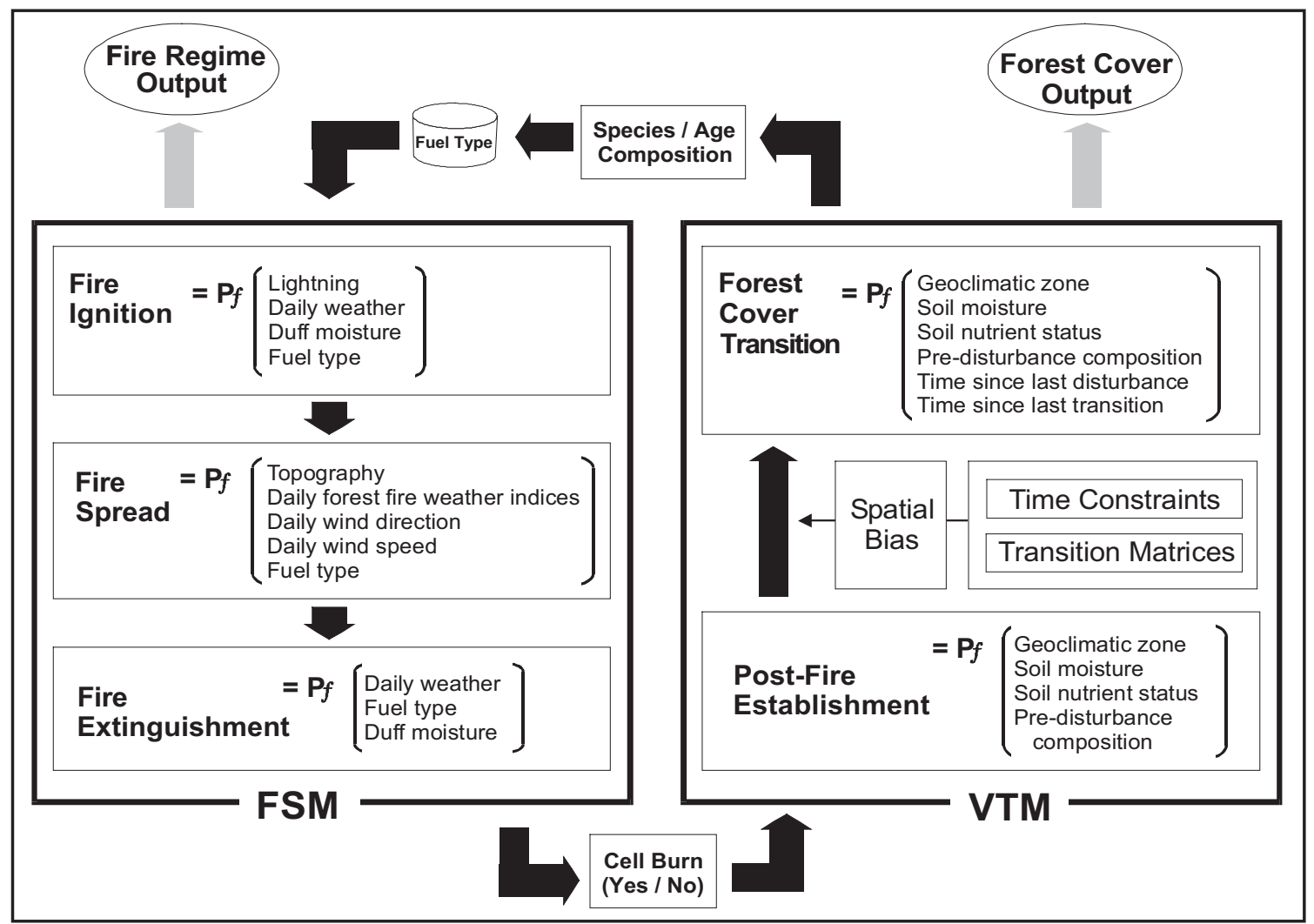

Fig. 2. Conceptual overview of the Boreal Forest Landscape Dynamics Simulator (BFOLDS) model (FSM = fire regime simulation module, VTM= vegetation transition module).

Table 1. Output information of the Boreal Forest Landscape Dynamics Simulator (BFOLDS)

\begin{tabular}{|c|c|c|}
\hline \multirow[b]{2}{*}{ Category } & \multicolumn{2}{|c|}{$\begin{array}{l}\text { Explicitness of } \\
\text { Information }\end{array}$} \\
\hline & Aspatial & Spatial \\
\hline \multicolumn{3}{|l|}{ Annual statistics } \\
\hline \multicolumn{3}{|l|}{ Fire regime } \\
\hline Number of burns & $\mathrm{y}$ & $\mathrm{n}$ \\
\hline Total area burned & $\mathrm{y}$ & $\mathrm{y}$ \\
\hline Spatial geometry of burns & $\mathrm{y}$ & $\mathrm{y}$ \\
\hline Size-class distribution of burns & $\mathrm{y}$ & $\mathrm{n}$ \\
\hline \multicolumn{3}{|l|}{ Landscape Structure } \\
\hline Species composition & $\mathrm{y}$ & $\mathrm{y}$ \\
\hline Canopy age composition & $\mathrm{y}$ & $\mathrm{y}$ \\
\hline Site age composition & $\mathrm{y}$ & $\mathrm{y}$ \\
\hline Spatial geometry & $\mathrm{y}$ & $\mathrm{y}$ \\
\hline \multicolumn{3}{|l|}{ Overall statistics } \\
\hline \multicolumn{3}{|l|}{ Fire regime } \\
\hline Temporal variation of number of burns & $\mathrm{y}$ & $\mathrm{n}$ \\
\hline Temporal variation of area burned & $\mathrm{y}$ & $\mathrm{n}$ \\
\hline Spatial tendency of burns & $\mathrm{y}$ & $\mathrm{y}$ \\
\hline Fire return interval & $\mathrm{y}$ & $\mathrm{y}$ \\
\hline Spatial tendency of fire return interval & $\mathrm{y}$ & $\mathrm{y}$ \\
\hline Spatial geometry of burns & $\mathrm{y}$ & $\mathrm{y}$ \\
\hline Size-class distribution of burns & $\mathrm{y}$ & $\mathrm{y}$ \\
\hline \multicolumn{3}{|l|}{ Landscape Structure } \\
\hline Survivorship distribution & $\mathrm{y}$ & $\mathrm{n}$ \\
\hline Temporal variation of canopy age-class distribution & $\mathrm{y}$ & $\mathrm{n}$ \\
\hline Temporal variation of site age-class distribution & $\mathrm{y}$ & $\mathrm{n}$ \\
\hline Spatial tendency of landscape aging (canopy) & $\mathrm{y}$ & $\mathrm{y}$ \\
\hline Spatial tendency of landscape aging (site) & $\mathrm{y}$ & $\mathrm{y}$ \\
\hline Temporal variation of species composition & $\mathrm{y}$ & $\mathrm{y}$ \\
\hline Spatial tendency of species occurrence & $\mathrm{y}$ & $\mathrm{y}$ \\
\hline Spatial tendency of species-age occurrence & $\mathrm{y}$ & $\mathrm{y}$ \\
\hline
\end{tabular}

\section{Landscape ageing patterns}

The average annual burn rate was $1.37 \% \pm 0.61$ of the study area (25 replicates of 200 -year simulation periods). However, this does not represent the complete picture as the mean annual area burned varied widely (from $5.14 \%$ to $<0.04 \%$ ) over the 200 -year period (Fig. 3). Extremes of annual burn rates ranged from $28.5 \%$ to $0 \%$ due to the stochastic model processes, even without enforcing artificial climate extremes in the input. The resulting site-age class distribution, after 200 years of uncontrolled fire disturbance, differed markedly from the initial age composition, and approached a negative exponential pattern where the younger age classes dominated (Fig. 4). At the $200^{\text {th }}$ year, $13.5 \% \pm 0.9$ of the study area had reached over 100 years, $4.2 \% \pm 0.4$ over 160 years, and $1.8 \% \pm 0.1$ over 200 years. The proportion of the study area in older site-age categories fluctuated during the simulation runs (Fig. 5). The proportion of the study area older than 100 years was lower $(13.5 \%)$ at the end of the simulation period than initially (21.9\%). However, the proportion of the study area $>150$ years and $>200$-years area increased considerably during the simulation period (from 1.1 to $6.2 \%$ in $>150$-year category and from $<0.007$ to $1.8 \%$ in $>200$-year category). The difference between canopy age and site age became apparent during the simulation period, even with the assumption that they were similar at the beginning of simulation runs, as illustrated by the $>100$-year-old area in Fig. 6 . At the end of the simulation period, the area with canopies older than 100 years $(7.2 \pm 0.5 \%)$ was nearly half of the area with site older than 100 years $(13.5 \pm 0.9 \%)$.

Spatial distribution of age-class structure (both site age and canopy age) following a simulation of a 200 -year uncon- 

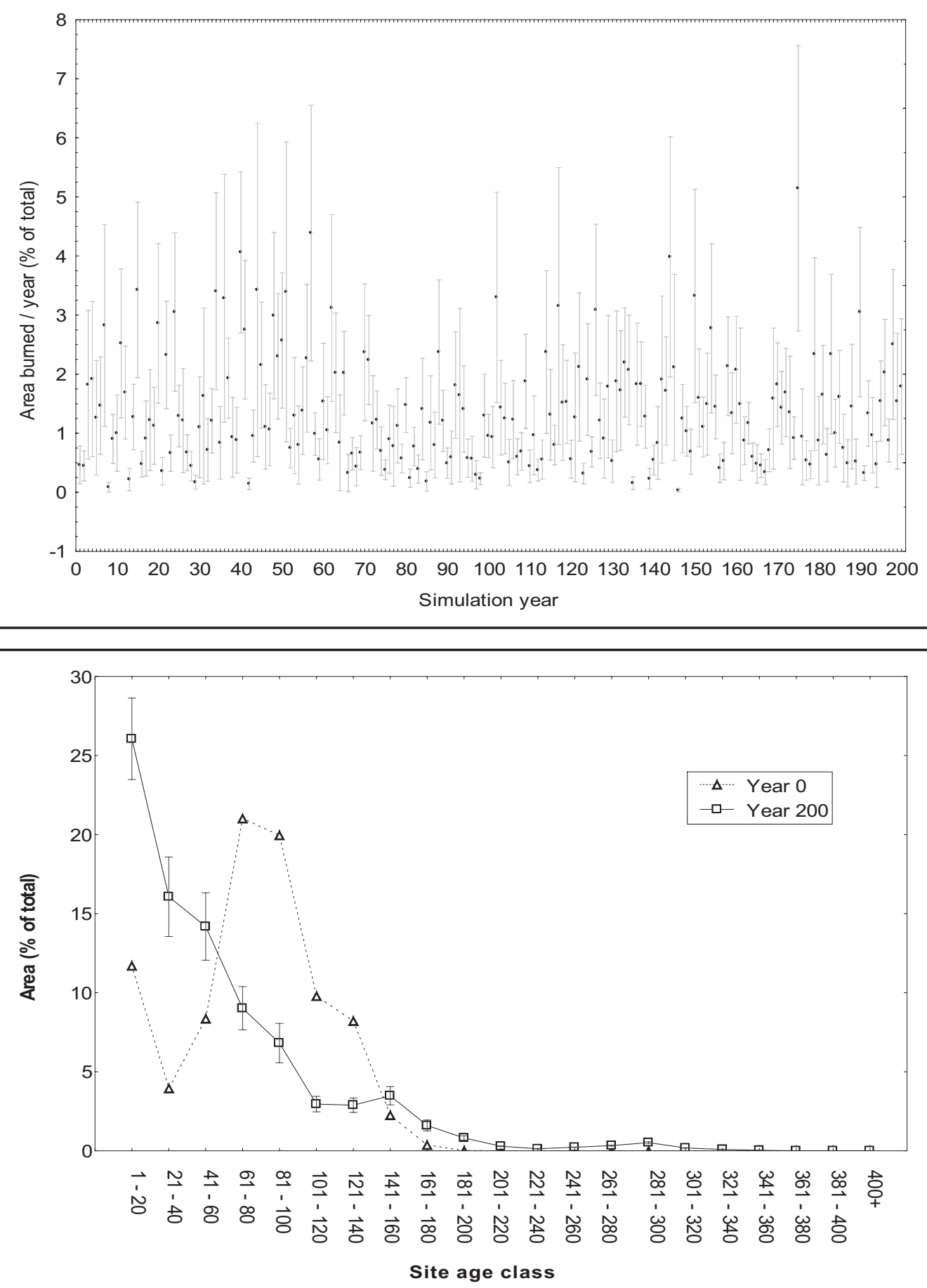

Fig. 3. Annual area burned (mean \pm std. error) in the study area during 200-year disturbance dynamics simulation period $(\mathrm{n}=25)$.
Fig. 4. The distribution of site-age classes of the study area at the start of disturbance dynamics simulations and at the end of the simulation period $(\mathrm{n}=25)$. trolled fire disturbance regime was different from the initial conditions (Fig. 7). The spatial distribution of average period between successive fires (fire return interval) was not homogeneous throughout the study area (Fig. 8). Few parts of the study area remained unburned during the simulations and, therefore, denoted a fire return interval $>200$ years. Based on the average fire return interval of each pixel and their frequency of burning, we generated spatial probabilities of ageing (i.e., the probability of each 1-ha pixel reaching a specified site age). These values were then aggregated for the whole study area to estimate the spatial tendency of landscape ageing. For example, the spatial distribution of probabilities of the study area reaching older ages is illustrated in Fig. 9. Furthermore, the proportion of the study area that can reach different ages, with known probabilities can be estimated as shown in Fig. 10. For example, $61 \%$ of the study area has zero probability of reaching 200 years $(27 \%$ for 150 years, and $15 \%$ for 100 years). On the other hand, $0.09 \%$ of the area has a probability higher than 0.5 of ageing to 200 years ( $1.5 \%$ for 150 years and $46 \%$ for 100 years). 

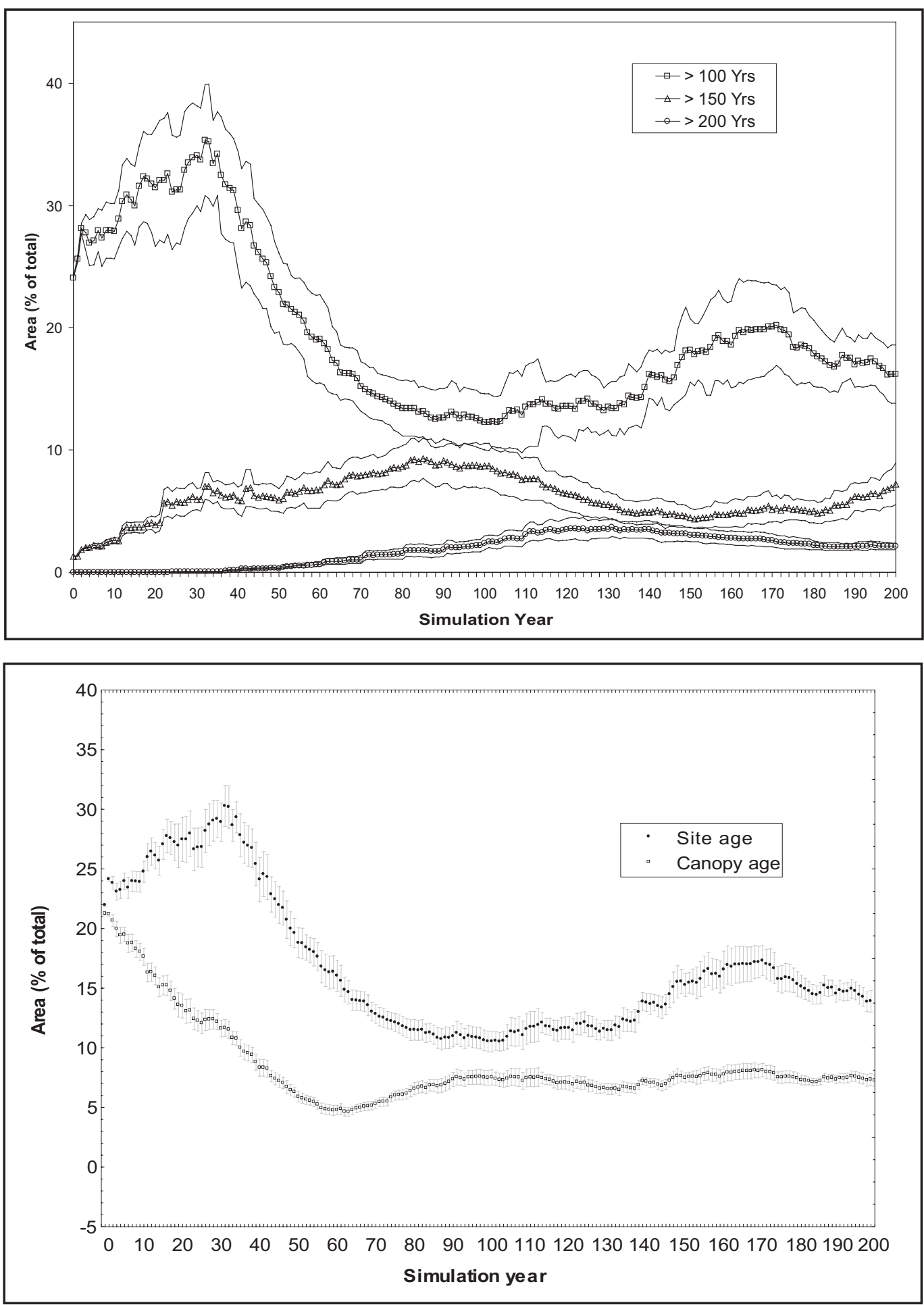

Fig. 5. Mean extent ( \pm std. error) of the study area in different site-age classes during the disturbance dynamics simulation period $(n=25)$
Fig. 6. Mean extent $( \pm$ std. error) of the study area in $>100$-year canopy age class and $>100$-year site-age class during the disturbance dynamics simulation period $(n=25)$.

\section{Potential for old growth}

The knowledge generated by simulating the fire disturbance regime and landscape ageing patterns is useful for estimating old growth potential from several viewpoints. To aid the following discussion, we arbitrarily assumed that 100 , 150 , and 200 years (site ages) represent some ecologically significant older forest types. First, model simulations demonstrate that the disturbance regime is variable and, therefore, the area under older age classes varies with time. Therefore, point estimates of old growth extent derived from present-day older age classes (or from one point of time in history) may not be good indicators of the true potential for old growth. Through simulations, a range of proportions of older age classes that can be sustained after a long period (in this case 200 years) of a "natural" disturbance regime can be directly quantified $(13.5 \% \pm$ 0.9 for $>100$ years, $6.2 \% \pm 0.6$ for $>150$ years), with their temporal variations (e.g., Fig. 5). If the present-day old forest extents are used to estimate the potential for older forests, the $>100$-year old-growth forest extent would be overestimated ( $21.9 \%$ versus $13.5 \%$ ), and the extent of $>150$-year and $>200$ - 
(a)

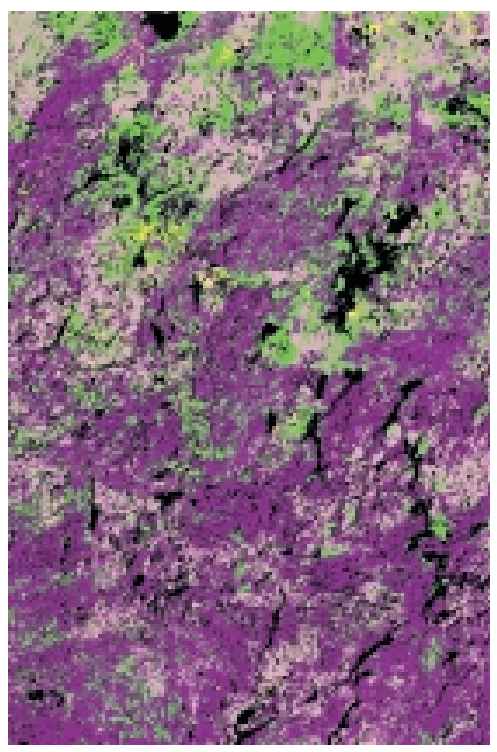

(b)

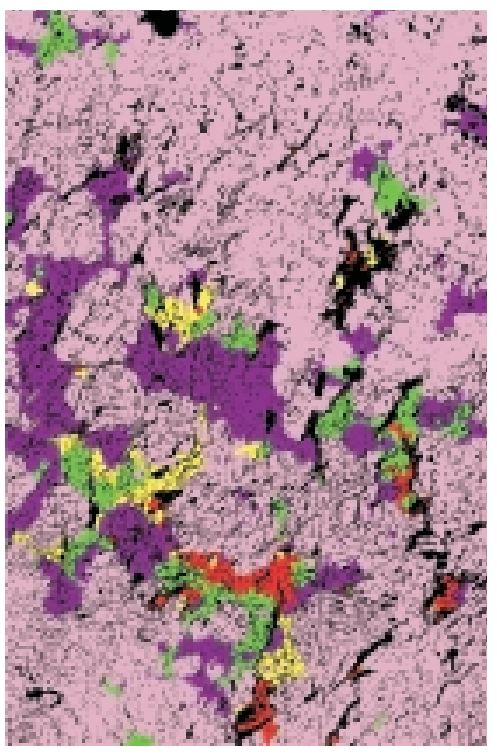

(c)

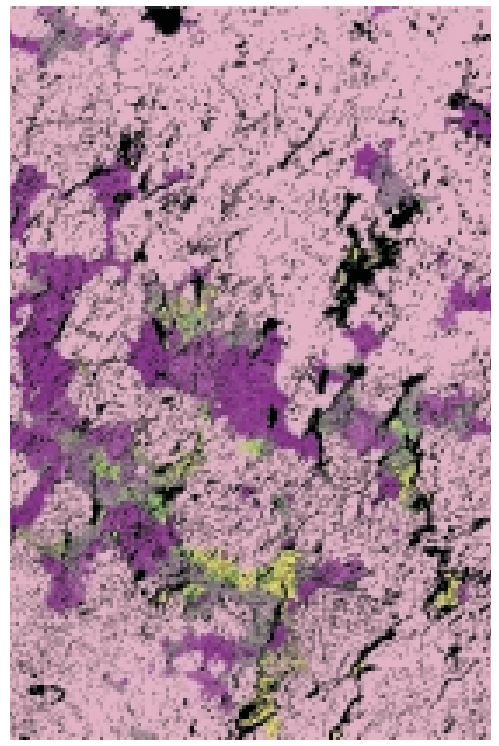

Site Age $\square<50 \quad \square 50-100 \square 100-150 \square 150-200 \square>200 \square$ Non-Forest

Fig. 7. Spatial distribution of site-age classes in the study area a) at the beginning of disturbance dynamics simulation, in comparison with one replicate at the end of 200-year period of disturbance dynamics simulations, b) site-age classes, and c) canopy-age classes.

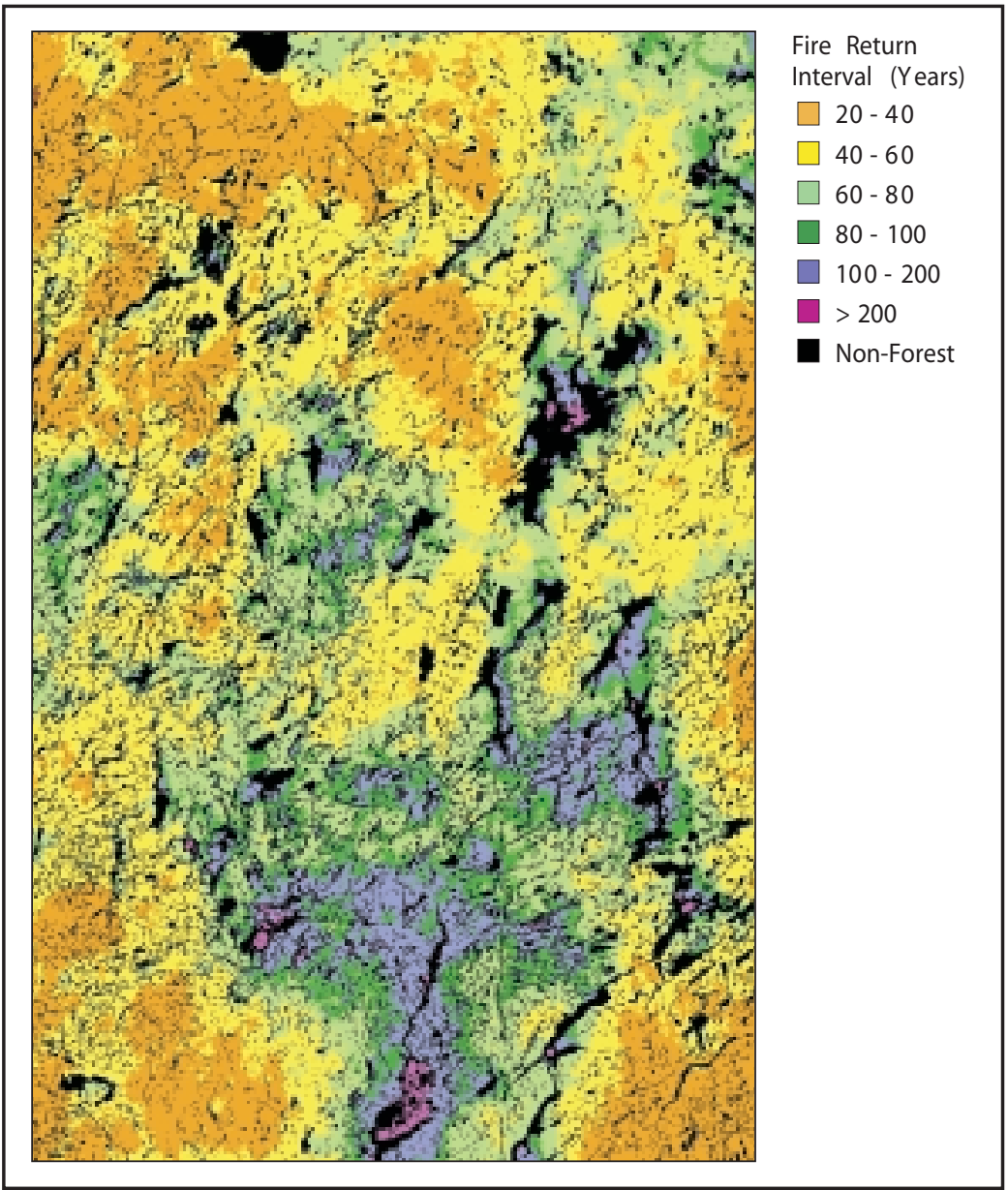

Fig. 8. Spatial distribution of the fire return interval in the study area $(n=25)$. 
(a)

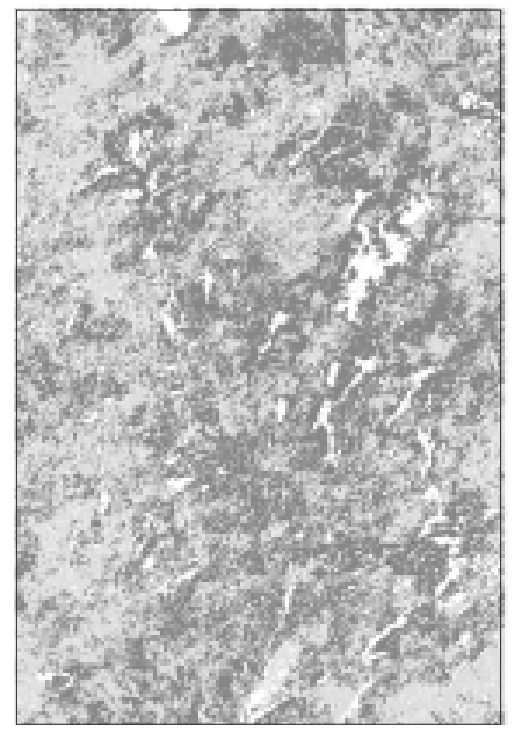

(b)

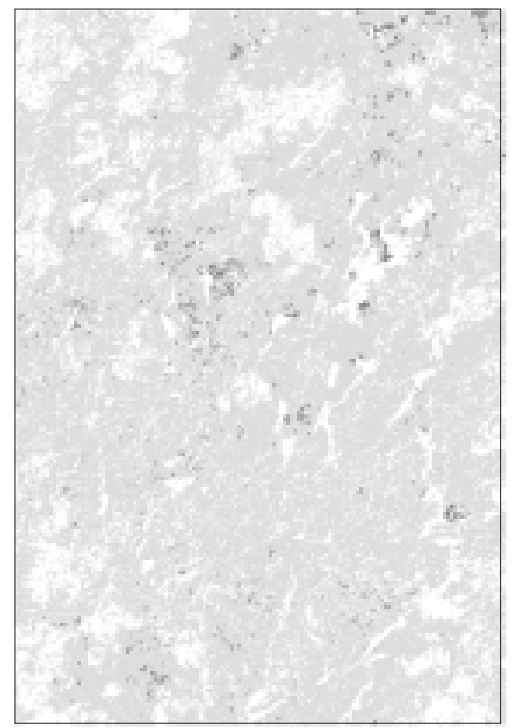

(c)

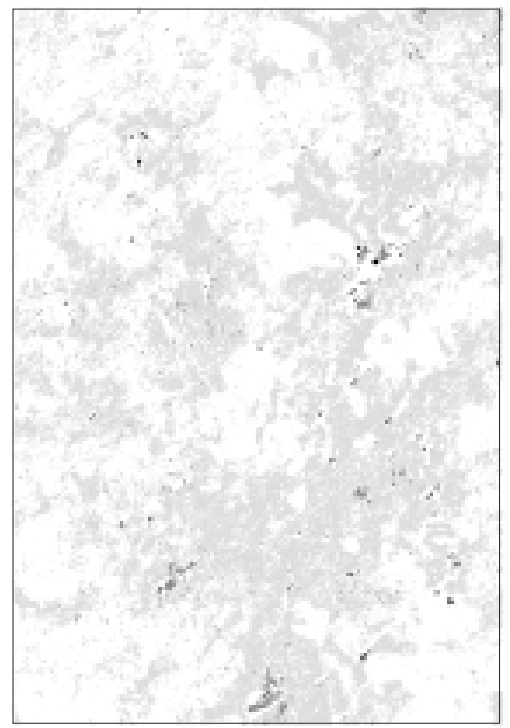

Probability of reaching the specified age

$\square 0$

$0-0.5$

$0.51-0.99$

Fig. 9. Spatial distribution of landscape ageing potential in the study area based on simulation of disturbance dynamics for 200 years $(n=$ 25), with probabilities of reaching specified site ages a) 100 years, b) 150 years, and c) 200 years.

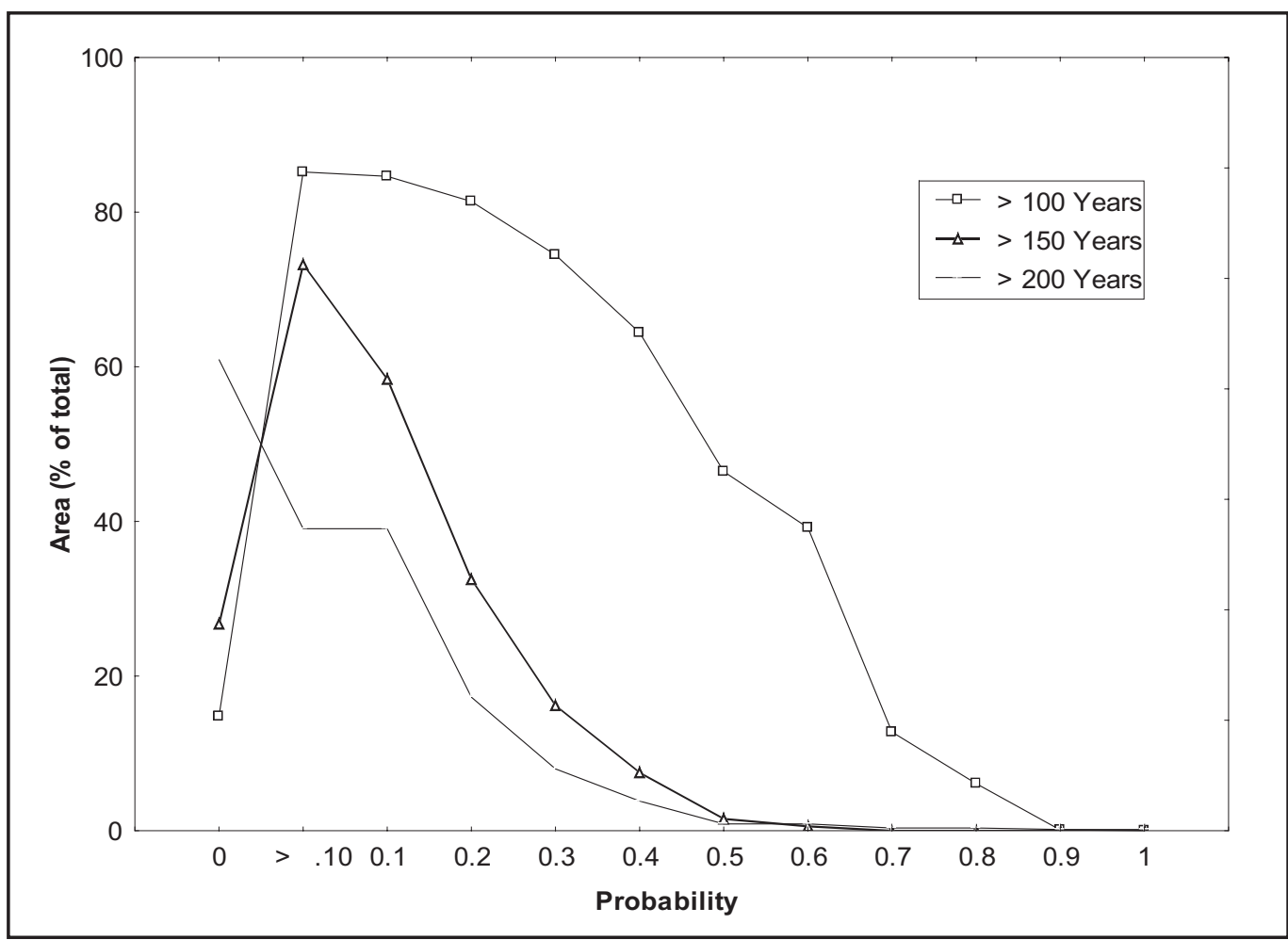

Fig. 10. The proportion of the study area reaching a specified site age with given probabilities.

year old-growth forest extent underestimated (1.1\% versus $6.2 \%$ and $<0.01$ versus $1.8 \%$, respectively). Collectively, this information will help answer the "how much old growth can be sustained" question of forest landscape planning.
Second, the spatial potential for old growth can be determined based on a probability assessment. For example, from Fig. 10, it can be deduced that $0.01 \%$ of the study area has a probability of 0.7 of sustaining 150 -year old-growth forest, or that $6.1 \%$ 
of the study area has a probability of 0.8 of sustaining 100 -year old-growth forest. Consequently, those parts of the landscape where a desired older age class can be sustained with known probabilities (as discussed above) can be spatially demarcated as shown in Fig. 9. Furthermore, the spatial geometry of the selected areas, and that of the entire landscape, can also be quantified to provide supplementary information (e.g., nearest neighbourhood distance, juxtaposition, forest core area). Collectively, this knowledge assists in answering the question of "where to locate old growth."

Third, it provides information necessary to define oldgrowth forests in a regional context. For example, based on the survivorship distribution at the $200^{\text {th }}$ year, the oldest $10 \%$ of the landscape area was $>120$ years, and the oldest $5 \%$ was $>$ 160 years. This, in combination with spatial probabilities of species occurrence, can be used derive predicted age-species definitions of old-growth forests (e.g., 120-year species A, 160-year species B). Conversely, if species, not site age, is the focus, survivorship distributions can be constructed for the canopy age of featured species, and species-age definitions can be derived for the simulated area. This approach, however, may be less desirable because the use of canopy age underestimates the proportion of landscape in older site-age classes, for example, by almost $50 \%$ in this study.

\section{General Conclusions}

In this case study, we illustrated the spatial simulation of forest landscape ageing patterns as a generic method of answering some questions about planning for old-growth forests. This approach complements other popular methods, such as natural history techniques and other empirical methods, and provides contextual insight to old-growth planning questions for forest landscapes where periodic allogenic disturbances are frequent at large spatial scales. Within the model assumptions, spatial simulations also provide estimates of spatial, temporal, and random variability of predictions of forest landscape ageing patterns, which cannot be readily captured through point estimates derived through natural history methods. In addition, mechanistic simulation methods can be improved incrementally as the scientific knowledge of ecological processes improves. For example: it may be possible to integrate the effects of fire regimes mechanistically with other disturbance regimes, such as insect epidemics and windthrow. Furthermore, once the spatial knowledge of climate change and its effects on disturbance regimes and species migration improves, it may be possible to simulate even longer-term trends of landscape ageing. Despite these advantages, there appears to be a general reluctance among practitioners to employ simulation modelling methods, even with scientifically sound models, due in part to their relative unfamiliarity with the subject matter, ambiguity in documenting model techniques by model developers, and the scarcity of reliable input data. However, future use of spatial simulation approaches in forest landscape planning is promising, given the prolific emergence of models that spatially predict forest landscape disturbance regimes and wide availability of GIS data layers.

\section{Acknowledgements}

We thank Ontario Ministry of Natural Resources for funding this research, Jim Caputo of the Fire Science and Technology Section of Ontario Ministry of Natural Resources for provid- ing fire weather information, two anonymous reviewers, and Ian Thompson of the Canadian Forest Service for reviewing an earlier draft, and Lisa Buse of the Ontario Forest Research Institute for editing the manuscript.

\section{References}

Agriculture and Agri-Food Canada. 1996. Soil landscapes of Canada. Version 2.2, National Soil Data Base, Ottawa, Ontario.

Barnes, B.V. 1989. Old-growth forests of the northern Lake States: a landscape ecosystem perspective. Natural Areas Journal 9: 45-57. Bergeron, Y. 2000. Species and stand dynamics in the mixed woods of Quebec's southern boreal forest. Ecology 81 (6): 1500-1516.

Boychuk, D. and A.H. Perera. 1997. Modeling temporal variability of boreal landscape age-classes under different fire disturbance regimes and spatial scales. Canadian Journal of Forest Research 27: 1083-1094.

Centre for Topographic Information. 2000. Canada digital elevation data: standards and specifications. Natural Resources Canada, Ottawa, Ontario.

Clark, J.S., M. Silman, R. Kern, E. Macklin and J. HilleRisLambers. 1999. Seed dispersal near and far: patterns across temperate and tropical forests. Ecology 80 (5): 1475-1494.

Cunningham, A.A. and D.L. Martell. 1973. A stochastic model for the occurrence of man-caused forest fires. Canadian Journal of Forest Research 3: 282-287.

Egan, D. and E.A. Howell. 2001. The historical ecology handbook: a restorationist's guide to reference ecosystems. Island Press, Washington, DC. $457 \mathrm{p}$.

Finney, M.A. 1999. Mechanistic modeling of landscape fire patterns. In D.J. Mladenoff and W.L. Baker (eds.). Spatial modeling of forest landscape change: approaches and applications. pp. 186-209. Cambridge University Press, Cambridge.

Forest Fire Danger Group. 1992. Development and structure of the Canadian forest fire behaviour prediction system. Forestry Canada, Fire Danger Group, Ottawa, Ontario. 65 p.

Frelich, L.E., R.R. Calcote and M.B. Davis. 1993. Patch formation and maintenance in an old-growth hemlock-hardwood forest. Ecology 74: 513-527.

Gardner, R.H., W. H. Romme and M.G. Turner. 1999. Predicting forest fire effects at landscape scales. In D.J. Mladenoff and W.L. Baker (eds.). Spatial modeling of forest landscape change: approaches and applications. pp. 163-185. Cambridge University Press, Cambridge. Gillis, M.D. and D.G. Leckie. 1993. Forest inventory mapping procedures across Canada. Forestry Canada, Petawawa National Forest Institute, Chalk River, Ontario. 79 p.

Greene, D.F., J.C. Zasada, L. Sirois, D. Kneeshaw, H. Morin, I. Charron and M.-J. Simard. 1999. A review of the regeneration dynamics on North American boreal forest tree species. Canadian Journal of Forest Research 29: 824-839.

Harris, L.D. 1984. The fragmented forest: island biogeography theory and the preservation of biotic diversity. University Chicago Press, Chicago, Illinois. $182 \mathrm{p}$.

Heinselman, M.L. 1973. Fire in the virgin forests of the Boundary Waters canoe area, Minnesota. Quaternary Research 3: 329-382.

Hills, G.A. 1959. A ready reference to the description of the land of Ontario and its productivity (a compendium of maps, charts, tables and brief comments). Ontario Department of Land and Forests, Toronto, Ontario. Preliminary Research Report. 142 p.

Hunter, M.L. 1989. What constitutes an old-growth stand? Journal of Forestry 87(8): 33-35.

Johnson, E.A., G.I. Fryer and M.J. Heathcott. 1990. The influence of man and climate on frequency of fire in the interior wet belt forest, British Columbia. Journal of Ecology 78: 403-412.

Johnson, E.A., K. Miyanishi and H. Kleb. 1994. The hazards of interpretation of static age structures as shown by stand reconstructions in a Pinus contorta-Picea engelmannii forest. Journal of Ecology 82: 923-931. 
Johnson, E.A., K. Miyanishi and J.M.H. Weir. 1995. Old-growth, disturbance, and ecosystem management. Canadian Journal of Botany 73: 918-926.

Johnson, E.A. and C.E. van Wagner. 1985. The theory and use of two fire history models. Canadian Journal of Forest Research 15: 214-220.

Keane, R.E., P. Morgan and S.W. Running. 1996. FIRE-BGCa mechanistic ecological process model for simulating fire succession on coniferous forest landscapes of the northern Rocky Mountains. USDA Forest Service, Intermountain Forest Range Experiment Station, Ogden, Utah. Research Paper INT-RP-484. 122 p.

Kneeshaw, D.D. and P.J. Burton. 1998. A functional assessment of old-growth status: a case study in the sub-boreal spruce zone of British Columbia. Natural Areas Journal 18: 295-310.

Lertzman, K., J. Fall and B. Dorner. 1998. Three kinds of heterogeneity in fire regimes: at the crossroads of fire history and landscape ecology. Northwest Science 72: 4-23.

Logofet, D.O. and E.V. Lesnaya. 2000. The mathematics of Markov models: what Markov chains can really predict in forest successions. Ecological Modelling 126: 285-298.

McKenzie, D., D.L. Peterson and J.K. Agee. 2000. Fire frequency in the interior Columbia River Basin: building regional models from fire history data. Ecological Applications 10: 1497-1516

Mladenoff, D.J., M.A. White, J. Pastor and T.R. Crow. 1993. Comparing spatial pattern in unaltered old-growth and disturbed forest landscapes. Ecological Applications 3: 294-306.

Ontario Ministry of Natural Resources. 1977. A ready reference. Ontario Land Inventory (a guide to the reading and understanding of the maps produced by the Ontario Land Inventory). Ontario Ministry of Natural Resources, Toronto, Ontario. 74 p.

Ontario Ministry of Natural Resources. 1996. Forest Resource Inventory Database Manual. Ontario Ministry of Natural Resources, Toronto, Ontario. 84 p.

Ontario Ministry of Natural Resources. 2000. Ontario Climate Model Version 2.0. Ontario Ministry of Natural Resources, Sault Ste. Marie, Ontario. CD-ROM.

Perera, A.H., D.J. Baldwin, F. Schnekenburger, J.E. Osborne and R.E. Bae. 1998. Forest fires in Ontario: a spatio-temporal perspective. Ontario Forest Research Institute, Ontario Ministry of Natural Resources, Sault Ste. Marie, Ontario. Forest Research Report No. 147. $22 \mathrm{p}$.

Perera, A.H., D. Yemshanov, F. Schnekenburger, K. Weaver, D.J.B. Baldwin and D. Boychuk. (In press). Boreal FOrest Landscape Dynamics Simulator (BFOLDS): a grid-based spatially stochastic model for predicting crown fire regime and forest cover transition. Ontario Ministry of Natural Resources, Ontario Forest Research Institute, Sault Ste. Marie, Ontario. Forest Research Report No. 152

Reich, P.B., P. Bakken, D. Carlson, L.E. Frelich, S.K. Friedman and D.E. Grigal. 2001. Influence of logging, fire, and forest type on biodiversity and productivity in southern boreal forests. Ecology 82 : 2731-2748.
Rowe, J.S. 1972. Forest regions of Canada. Canadian Forest Service, Ottawa, Ontario. Publication No. 1300. 171 p.

Rupp, T.S. 1998. Boreal forest regeneration dynamics: modeling early forest establishment patterns in interior Alaska. Ph.D. Dissertation. University of Alaska, Fairbanks, Alaska. 242 p.

Sirois, L. and S. Payette. 1989. Postfire black spruce establishment in subarctic and boreal Quebec. Canadian Journal of Forest Research 19: 1571-1580.

Spies, T.A. and J.F. Franklin. 1988. Old-growth forest dynamics in the Douglas-fir region of western Oregon and Washington. Natural Areas Journal 8: 190-201.

Spies, T.A. and J.F. Franklin. 1996. The diversity and maintenance of old-growth forests. In R.C. Szaro and D.W. Johnston (eds.). Biodiversity in managed landscapes. pp. 296-314. Oxford University Press, New York, NY.

Suffling, R., M. Evans and A. Perera. 2003. Presettlement forest in southern Ontario: Ecosystems measured through a cultural prism. The Forestry Chronicle 79(3) 485-501.

van Wagner, C.E. 1987. Development and structure of the Canadian forest fire weather index system. Canadian Forest Service, Ottawa, Ontario. Forest Technical Report 35. 37 p.

Vasconcelos, M.J.P. and B.P. Zeigler. 1993. Discrete-event simulation of forest landscape response to fire disturbance. Ecological Modelling 65:177-198.

Weaver, K. 2002. Spatial bias in landscape ecological simulations: case study of accounting for spatial dependence in a raster-based stochastic model using a region approach. M.Sc. Thesis. University of Toronto, Toronto, Ontario. 129 p.

Wimberly, M.C. and T.A. Spies. 2001. Influences of environment and disturbance on forest patterns in coastal Oregon watersheds. Ecology 82:1443-1459.

Wimberly, M.C., T.A. Spies, C.J. Long and C. Whitlock. 2000. Simulating historical variability in the amount of old forests in the Oregon Coast Range. Conservation Biology 14:167-180.

Yemshanov, D.G. and A.H. Perera. 2001. Modelling boreal forest succession at broad scales: a North American bibliography. Ontario Ministry of Natural Resources, Forest Research Institute, Sault Ste. Marie, Ontario. Forest Research Information Paper No. 146. 46 p. Yemshanov, D.G. and A.H. Perera. 2002. A spatially explicit stochastic model to simulate forest cover transitions: general structure and properties. Ecological Modelling 150: 189-209.

Zasada, J.C., T.L. Sharik and M. Nygren. 1992. The reproductive process in boreal forest trees. In H.H. Shugart, R. Leemans and G.B. Bonan (eds.). pp. 85-125. A systems analysis of the global boreal forest. Cambridge University Press, Cambridge. 